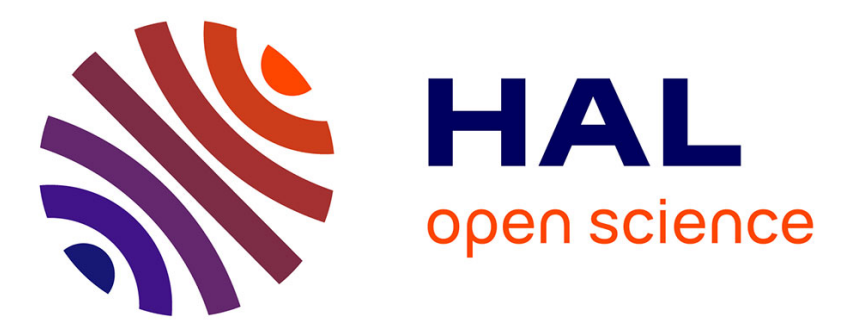

\title{
The genesis of economic thought concerning war and peace
}

\author{
Jacques Fontanel, Fanny Coulomb
}

\section{To cite this version:}

Jacques Fontanel, Fanny Coulomb. The genesis of economic thought concerning war and peace. Defence and Peace Economics, 2008, War and Peace Issues in the History of Economic Thought, 19 (5), pp.321-330. 10.1080/10242690802354261 . hal-02059641

\section{HAL Id: hal-02059641 \\ https://hal.univ-grenoble-alpes.fr/hal-02059641}

Submitted on 6 Mar 2019

HAL is a multi-disciplinary open access archive for the deposit and dissemination of scientific research documents, whether they are published or not. The documents may come from teaching and research institutions in France or abroad, or from public or private research centers.
L'archive ouverte pluridisciplinaire HAL, est destinée au dépôt et à la diffusion de documents scientifiques de niveau recherche, publiés ou non, émanant des établissements d'enseignement et de recherche français ou étrangers, des laboratoires publics ou privés. 
Defence and Peace Economics, 2008 Vol. 19(5), October, pp. 321-330

\title{
THE GENESIS OF ECONOMIC THOUGHT CONCERNING WAR AND PEACE
}

\author{
JACQUES FONTANEL AND FANNY COULOMB ${ }^{\dagger}$ \\ University of Grenoble, CREPPEM, France \\ (Received 18 December 2007; in final form 18 July 2008)
}

This article links the development of political and philosophical thought with that of economic thought concerning war and peace issues. The economic orthodoxy that emerged during the 17th century presented human relations as peaceful, society being governed by a 'natural order', the Smithian 'invisible hand'. On the other hand, political theory saw emerging a realistic view with human relations characterized by violence, with conflict being society's normal state. This dichotomy explains the relative scarcity of economic studies on war and peace issues and the fact that these have been more often studied by heterodox authors.

Keywords: War; Peace; Philosophy; Political scientists; English classicists; Mercantilism; List; Marxism JEL Codes: B1; B2; B31; B51

The history of economic thought calls into question the argument of Jean-Baptiste Say that the discovery of 'real' economic laws dooms all previous economic researches to oblivion. Thus, a contemporary French economist, André Lapidus (1996) refutes the ability of 'economic science' to demonstrate the erroneousness of certain economic theories, except (of course) as regards a limited number of specific technical or logical points. However, the fact remains that a large body of knowledge accumulated by economists is forgotten today. This is true for the economic analysis of peace and of its sinister reflection, namely war.

- An analysis of the economic theories of war, peace and defence highlights the assumptions and the thoroughness of economists' thoughts on the issues of war, peace and international security. A more rigorous analysis shows that the excessively 'warmongering' and 'mercantile' character attributed to the mercantilist school is reducible. It also helps to show the evolution of Keynes's thought according to the actual circumstances of war or peace (Coulomb, 1997).

- New conceptions of peace are often repetitions of ideas expressed earlier. Such research can provide useful elements for a deeper meditation on the economics of defence, even though reference to these theories is sometimes only of historical interest. It helps to define argumentation by appealing to analyses undertaken previously, and through 'reactivation of forgotten knowledge'.

- - It is helpful to emphasize the breadth of fields and topics, which are touched upon, to underline their interest or the inadequacy of their treatment and to identify the main theories or doctrines. Given the importance of the economy in today's decisionmaking, it is clear that economic theory exerts a decisive influence on development 
of our societies, and particularly on the trust, which we place in the processes of globalization, regionaliza- tion and the unstable coupling of armament and disarmament. Analysis of economic thought offers a deep reflection on the importance and future direction of the economics of defence, peace and war. The evolution of contemporary international economic relations is characterized by open borders and interdependence, but also by the growing instance of domination and inequality effects. What is the economic status of war, peace and defence today? Is it different from yesterday? If so, how and why?

There is a shortage today of analyses that seek to 'theorise' war, international security or national defence. However, the interest of such analysis is clear. Although there are few authors who have devoted specific chapters to the analysis of war and peace, there are also few great economists who have studied these issues, from Jean Bodin to Adam Smith, from Robert Malthus to Friedrich List, from Karl Marx to Leon Walras, from John Maynard Keynes to contemporary economists such as Kenneth Arrow, Lauwrence Klein or Amartya Sen.

The change, by which the economy became an autonomous field of analysis, with the gradual disappearance of studies concerning defence, security and war in favour of political analysis, dates from the start of modern economic development. When economic science imposed itself on political economy, it rejected from its analysis everything that went beyond the reductive assumptions, on which it was based. For the mercantilists, war and economic conflict were two inseparable facets of the Prince's will to power by all means on the interna- tional stage. In contrast, for the classical or neoclassical economists, wars with economic causes were destined to vanish because production of each political entity, determined by free trade and the law of comparative costs, should replace counterproductive acts of predation. If a military conflict is sometimes legitimate, particularly in combating other antagonistic systems, it is nevertheless partially excluded from the scope of economic analysis. A country engaged in a war aims to destroy its opponent and it mobilises national economic resources for this aim. So, war is inscribed in a logic, which is opposed to that of economics.

Economic reflections on conflict and war have been increasingly neglected nowadays, because of their apparent economic irrationality in a merchant world judged a priori to be essentially peaceful, globalized and streamlined. It has even been inferred that war is unrelated to the economy, or that economics can only cause armed conflict by accident. Most manuals that outline theories of international economic relations never consider this issue, as if the war or its threat were outside the scope of economic analysis. The ideal of universal peace, encouraged by the improvement of scientific knowledge, is a redundant theme of liberal economic thought. Mainstream economics today makes two undeclared assumptions:

(1) Peace is the normal state of affairs; 
. (2) Economic development, made possible by industrialization, is the fundamental instrument for sustainable peace.

However, this exclusion of defence and national security from the field of economic analy- sis is neither complete nor final, since heterodox theories exist. The contributions of economists on the issues of war and peace, security and defence, can be grouped into broad trends or ideas. Although the main trends of economic thought have coexisted, ideological dominance of one or other trend is a fact of history. The mercantilist conception initially had the upper hand, before it gave its place - via the elusiveness of physiocratic thought - to the liberal conception, which was then challenged by Marxist theory without actual suppression of previous analyses. However, this evolution of doctrines and theories has not continued in the same way since the end of the Second World War. Many interpretations of the relation- ship between defence and the economy now coexist, but the theme is not viewed as central and is not frequently analysed. Contemporary analyses are usually founded in one or other of the great movements from the history of economic thought. Thus, analysis of economic issues has escaped from its long influence by political philosophy and has established itself as an autonomous field of study.

\section{THE INFLUENCE OF PHILOSOPHERS AND POLITICAL SCIENTISTS}

Machiavelli wrote The Prince (1513) in Italy at the beginning of the 16th century. He placed war at the centre of government action, and proposed the goal of political stability to the detriment, if necessary, of the nation-enriching goal. Armed force is essential to ensure the superiority of the State and laws and moral principles can be maintained only if they are supported by a large military force. As a last resort, military force is more important than wealth. War is also a factor for the international distribution of wealth. The maintenance of a powerful army serves the State at both internal and external levels. The Prince uses foreign policy to eradicate any domestic dispute, but the political system also needs public support for the Prince's views. The members of the nation must withstand the common enemy, and that justifies respect of the social rules by all individuals. The militarization of society is desirable because it promotes the spread of values that strengthen social cohesion and a sense of belong- ing to a community. War is presented as a 'cure' for the disease of civil war or internal dispute. Machiavelli believes that a peaceful State is preferable to an aggressor State, in absolute terms, but the will to dominate is inscribed in the very nature of the State. 'There is no people, which loves freedom alone.' Machiavelli's thought supports the mercantilist analysis. The power of the Prince is the fundamental objective of the national economy, states seek both to organize social life and to organize themselves according to external constraints, and although war is not desirable, it is one means of achieving economic and political goals.

In the 17th century, Thomas Hobbes in Leviathan (1651) presents an anarchic conception of relationships between individuals, and a fortiori between states. Man is aggressive by nature, 'man is a wolf to man'. The state of war and its threat are 
permanent. People live together in a situation of constant insecurity, and are driven by self-preservation to join a social pact. They then abandon their natural rights in favour of absolute monarchic power, capable of preventing civil war and return to a violent state of nature. States are in a permanent state of war, which is even a condition for their survival. Peace is the absence of war, it is perceived negatively, and it is always artificial. The thought of Machiavelli and Hobbes inspired mercan- tilist reflection in a period when the State was being established and when the 'religious' discipline of Christianity was facing major challenges. Economic factors are not mentioned in these analyses, beyond highlighting the need for sufficient economic power to enforce order, amass war booty and have weapons to hand in case of armed conflicts. These ideas remain forceful today, and American policy in the 21 st century seems to be inspired by them.

In contrast, for Locke (Treaty on Civil Government, 1690), man is primarily a social being, inscribed in the natural law of a peaceful world. Man has a natural inclination towards mutual goodwill and reason that establishes the need for preservation of others as much as oneself. However, individuals are not completely rational, they do not always have a sense of right and they are subject to the passions of ambition and selfesteem. War is a consequence of the imperfection of human nature, but reason drives people to restore peace. A State cannot maintain itself if it does not gain its citizens' support. States conquered by force can never constitute a sustainable political community. Locke's thoughts directly inspired the physiocrat theory, which presents a concept of society governed by harmony of the interests of its various members, as well as liberal economic theories, according to which society is governed by a 'natural order', in which the State does not intervene. Man is basically good, as suggested by Jean-Jacques Rousseau and his social contract.

In opposition to the evolution of economic thought describing a society, in which the inter- ests of all people agree in accordance with a natural order, the major philosophical theories include the problem of conflict. The analysis of Immanuel Kant (1724-1804) solves the dilemma between the materialism of economists and idealism by suggesting that man is free and finds the moral law, which guides his action, inside himself. Social institutions organize the operation of a general law based on the free will of each individual. The liberal economic theory based on private property and free trade is thus justified. In addition, all mankind is driven by a 'purpose', a 'hidden plan of nature'. Thus, in the very long term, humanity will reach universal peace. Wars are morally unjustifiable, but they are a factor of the progress of societies to a state of perfect civilization, a worldwide federation characterized by universal and lasting peace. War makes and breaks governments, and reshapes international relations, helping to realize this unique State, which should be constitutionalist and federalist. So, human progress can then be achieved by resort to war. Kant's theory directly influenced the German history school, but also, to some extent, Marxist thought. Wars are essentially a moment in history, a section of the path towards the 'hidden plan of nature'. But the Kantian theory also had a major role in genesis of the thought of the German philosopher J.G. Fichte 
(1762-1814), who, in The Closed Trading State, assigns the central role in national life to the State. People must be mobilized to serve the higher objectives of the nation. All trade relations with other countries should be curtailed. The exaltation of a collective action made Fichte an apologist for the German nation and its civilizing mission. Mercantilism and liberalism are, therefore, also rejected, in favour of a form of 'state socialism', in an autarkic society. Then came Friedrich Hegel (1770-1831) who developed a theory of violence as a necessary step in the process of social transformation, inspiring, together with Feuerbach's historical materialism, Marxist thought. War builds humanity. The economy is only a means or a state of things that promotes or fails to promote the emergence of humanity.

Leading economists in the 18th and 19th centuries were also philosophers. Basically, they remind us that the economy requires a certain conception of men and society. In this context, war is part of the fibre of mankind, but is also essential to economics. For example, Adam Smith condemned colonial wars, citing the action of the 'invisible hand'. Karl Marx developed his theory on the basis of class struggle and historical materialism, putting forward a philoso- phy stamped by assumptions that will mark the economic laws that he deduces from the operation of capitalism. Walras also made an attempt at political philosophy, although without any great success. He believes that peace is an ultimate goal sought by economists when they strive to uncover the laws that govern functioning of the economy. Basically, economic knowledge is a factor for universal peace. According to this idea, the desire to create an economic science will gradually lead economic thought away from philosophical reflection, limiting its substance to generalities presented as inalienable truths.

\section{THE DEVELOPMENT OF ECONOMIC THOUGHT CONCERNING DEFENCE, SECURITY AND PEACE}

Starting from the 16th century, several authors propose to analyse economic factors in a histor- ical period marked by the emergence of nations and nation states in Europe, by the renewal of Renaissance thought, and by rehabilitation of the search for wealth through Reform in a context of expanding European trade. Mercantilism, the first recognized school of thought, has been criticized for its disparate ideas, but gave special attention to the sphere of economics, while respecting the primacy of politics. Economic power is regarded as a prerequisite for the political power of the Prince. The mercantilist doctrine legitimizes economic warfare, but it also legit- imizes a war of aggression, since political action must strengthen the power of the State. National economic independence is an ultimate objective of economic policy, because it is a condition for the power of a Prince, and it can be pursued to the possible detriment of citizens' wealth. The economy remains subordinated to the political sphere, in a context of internal political unifi- cation of states and conflicts between them over trade and colonial issues. Mercantilism proposed strengthening of central government action, using war to assert its power externally, but also to enhance national sentiment and the glory of the Prince domestically. 
The rise of capitalism led to the development of Smith's theory, by which the free operation of market mechanisms and free individual initiative ('the invisible hand') led society to a natural order, where all its members find their optimal interest. Therefore, the physiocrat and classical analyses affirm the primacy of the economic sphere and they show war as an econom- ically irrational phenomenon. The physiocrats argue that natural laws of economics have to do with a divine will. Harmony and universal peace flow from the absence of government inter- vention in the economic sphere. Like Mercantilism, Physiocratism legitimizes monarchical power, because the King is a representative of God. National power is always presented as an objective, but it is achieved more easily though peace than armed conflict.

The English classicists defended the idea of the existence of economic laws, which are imposed rationally upon man and whose functioning must not be impeded. However, national security must be looked after by the State, and is even, Adam Smith (1776) argues, a prerequisite for operation of the 'invisible hand' (Coulomb, 1998a). As defence belongs to the field of action of a State-controller, and therefore the public economy, it does not obey the same rules as prevail in the private economy. Security issues are partly put outside the scope of economic analysis, except for the need to create a war chest, the question of whose relative importance in peace time entails some minor debates. International economic relations are justified by the law of comparative advantage. In this context, the development of trade is a factor for peace. Admittedly, the classicists do not all share in equal measure the belief in long-term realisation of a prosperous and peaceful world by the free operation of market forces. Some authors, includ- ing Malthus (1798), even show themselves to be pessimistic about the inevitability of war's demise without political control of the population. Similarly, the realization over time of a static economy assumes the end of war, but also the disappearance of excessive wealth and greed for money. These differences reflect a persistent interest of economists in understanding and discussing problems related to defence, security, war and peace. So, although the mercantilist school is not completely overtaken by the fundamental economic analysis of the classicists, the latter dominates economic thinking for decades. The pacifist utopia underlies the emergence of new schools of economic thought. It develops with the thought of J.B. Say and continues thereafter throughout the history of liberal thought. The ideal of peace also inspires economist- reformers, such as the utopian socialists (Proudhon and Saint-Simon).

However, the liberal supremacy faced two major challenges of a different nature, originating from Germany. Friedrich List (1841) initially rejects the 'British' form of liberalism, based on a refusal to analyse and even to acknowledge the existence of relations of power in a Europe that is still divided, and in which the German nation has not yet found its place. He believes that free trade promotes the leading economic power of the time at the expense of other nations, whose natural boundaries have not yet been established. Under these condi- tions, he denies the application of market rules defined by Adam Smith and the operation of the 'invisible hand'. He stresses relations of force between nations as well as the uneven development of productive forces. List is the forerunner of the German 
historical school, which puts issues of defence and affirmation of the national economy at the forefront of economic analysis, calling for protectionist barriers and the use of military force as well as economic tools. Universal peace remains a desirable objective, but it will only be effective when all the countries of the world have attained the same level of economic development, and can unite in a broad confederation. List proposes a new form of mercantilism, mixing the political and military power of states with the goals of economic development.

At a time when liberal thinking was dominant, List's analysis challenged the order defined by British power. Following his analysis, another theory came onto the scene and upset the established formats of economic knowledge, a theory that spoke as the main competitor of liberalism, both in 'scientific' analysis and in the political and military arena. The Marxist theory rejected liberalism and viewed capitalism as the very foundation of war. Marx (1867) and Engels (1878) contest the peaceful nature of free trade, by pointing to the existence of global industrial war at enormous human cost. They found conflict at the very heart of capitalism, in the form of class struggle. Economic contradictions underlie any form of production, and all political phenomena, including war, stem from these contradictions. Therefore, economics and politics are inextricably linked. War is a preparatory step towards revolution and the establishment of communism. The theories of imperialism accorded a major place to conflict, colonialism and the power of states and of capital. The inevitability of war reflects the internal economic contradictions of capitalism, which led to its extinction, mainly through the development of revolutionary tendencies within society.

So, the dominance of liberal thought regarding peace was questioned first by List, and then by Marx. Marx's many detractors then sought to suppress the political nature of economic analysis. The political economy, therefore, with its philosophical reflection, tended to disap- pear (outside Marxism), to be replaced by a form of economics with a more scientific charac- ter. The neoclassical analysis of the 19th century neglected the study of the economic aspects of defence by qualifying defence as a political issue. Some neoclassicists even abandoned the idea that defence of national strategic interests can justify government intervention in the economy, including custom-duty barriers for retaliatory purposes or for the protection of stra- tegic goods. The marginalist analyses of Walras or Jevons placed war outside the scope of pure economics, for the same reasons as national security is placed outside the scope of economics. It then followed that military spending is a mere burden and the concept of war cannot be the result of economic calculations, but only of political considerations. Peace must prevail, tomorrow if not today, thanks to the advance of economic, social and human knowl- edge. Open borders must lead to universal peace. The neoclassical approach, by its very nature, is not intended to incorporate the defence issue. ${ }^{4}$ Rejection of 'political' problems as beyond the scope of orthodox economic analysis entails neglect of economic studies regard- ing defence, from the mid-19th century until the First World War. War is not a subject for economic analysis. The First World War was not anticipated by any of the liberal economists (Engels, by contrast, saw its approach), but it did not force orthodox 
economists to resume the study of defence issues. New thinking on the relationship between peace and war, defence and the economy were the contributions of a few heterodox economists.

The contribution of Keynesian theory can be found in the formulation of macroeconomic models, which seek to show the impact of military spending on national economies. These formalized systems are also used to assess the economic benefits that can be expected from disarmament or rearmament, according to a number of tested hypotheses.

The various contemporary extensions of Marxist theory and imperialism contribute to the understanding of phenomena related to defence. The military sector is regarded as a core element in the functioning of the capitalist system, as a guarantor of power without the sharing of capital.

Finally, a 'neo-mercantilist' current develops the concept of economic warfare. In a context of increasing internationalization of economies, and polarization of international economic relations, economic conflicts tend increasingly to replace military conflicts or to supplement them. Figure 1 highlights some significant relationships between the most important schools of economic thought on issues of war and peace. ${ }^{5}$

\section{ECONOMIC THOUGHT CONCERNING WAR AND PEACE 327}

Therefore the mercantilist school was substituted by the physiocrat and classical school. The latter was contested by List, who renewed mercantilist thought. This denial of liberal peace was strongly reinforced by Marxist analysis, which considered that peace can emerge only with the end of capitalism and the successive advents of socialism and communism. Faced with this new alternative thought, the marginalist stream proposed studying the economy scientifi- cally and to remove the political and military trappings, by which issues of war and peace made their entry. However, facts proved recalcitrant and the world wars of the twentieth century have not yet found any plausible economic explanations.

The two world conflicts undermined the doctrinal power of liberal economic theory, and encouraged the emergence of alternative analyses, which seek to draw lessons from history. The economic challenges posed by the management and the consequences of the conflict were studied by many famous economists, such as Pigou, Wicksell and Keynes. The weakening of democratic capitalism, in the face of fascism and communism, led prominent economists such as Keynes and Schumpeter to question its durability. With Keynesian theory, the State is no longer seen as a mere reflection of the sum of individual interests. The very right to conduct an appropriate public policy was attributed to the State. Current new initiatives in the econom- ics of defence are partly due to this theoretical evolution. The economy of defence has now focused its attention on arms 
production, military expenditures and international economic relations.

Two conceptions of the role of the economy in the emergence of wars are now prevalent in economic theory. On the one hand, conflict is excluded from the field of economic analysis and peace is seen as inherent to the free operation of market forces; on the other hand, conflict is embedded in the very heart of the analysis, and peace is viewed as achievable only through a challenge to the established capitalist system.

During the Cold War, a neoclassical analysis applied the methods of microeconomics, supplemented by new inputs from game theory, to the analysis of the opposition between two systems. Models of the arms race formalized the strategic behaviour of two antagonistic states in opposition, and the theory of alliances was developed. The development of new analytical techniques (including formal models and empirical tests) and the enrichment of neoclassical theory (e.g. inputs from game theory) enabled deeper understanding of mechanisms behind large-scale militarization of Western economies and measurement of the impact of military spending on economic development. However, the results of this analysis are not always meaningful when applied to the world (not always confirmed by the facts). 


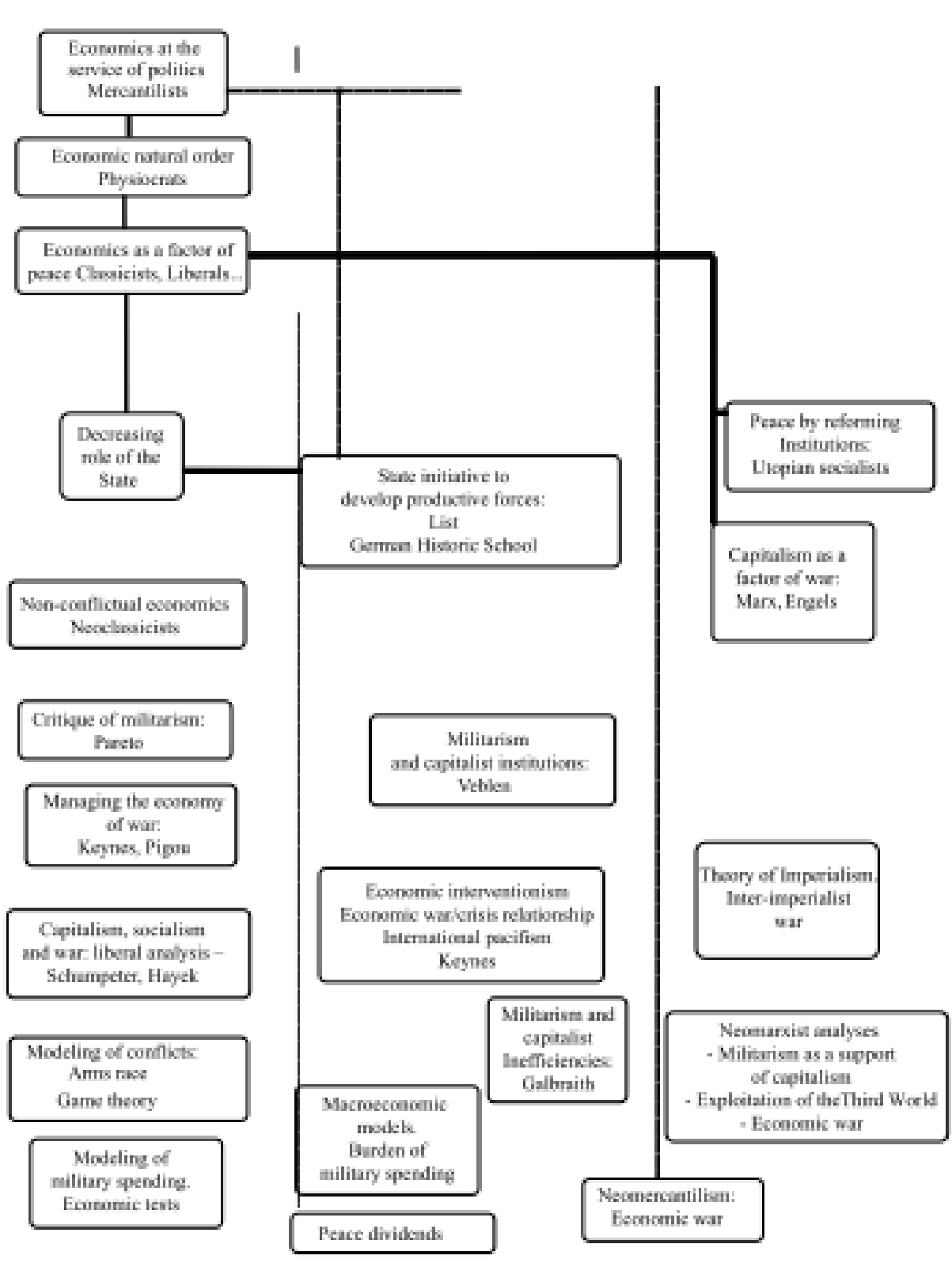




\section{CONCLUSION}

Security and defence are sovereign functions, and are undeniable and undisputed public goods. No state can, therefore, take any step in the economic domain without considering its impact on defence and national security, and taking into account the propensity to predation, which has been the cause of armed conflicts. Because of the importance of resources allo- cated to national defence, which has sometimes been viewed as the main spur for the devel- opment of compulsory levies, there is a difficulty in the treatment of military spending only in terms of the burden, which it represents with respect to peaceful welfare economics. The scope of peace and defence analysis can be broadened and embedded in the entirety of economic instruments for promotion of national interests, such as trade policy measures or import barriers. It is important to avoid the pitfall of international relations analysis based only on a concept of 'economic war', since that is implicitly to admit that states have nothing in common but conflicts and that solidarity has scant foundations. However, there is a real gap between economic reality and the development of orthodox economic theory, which has tended to dismiss the issue of conflict as being beyond the scope of economic analysis concerned only with the laws of ideal market operation.

Economic globalization is a key feature of international relations. The growing economic interdependence of national economies and the collapse of the Eastern Bloc seem to remove permanently the spectre of conflict between the major powers and to represent the triumph, announced in the 18th century, of liberalism over mercantilism, and of economics over poli- tics. In fact, though, defence analysis is more present in economic analysis today than it ever has been before. The instruments of economic warfare are today compared with those of military war. There is a close relationship between economic power and the military strength of states. The arms race between the United States and the Soviet Union reflected strategic factors, but it was also an 'economic war' in a very real sense, as evidenced by the collapse of the Soviet economy, exhausted by the effort of supporting an exceptional military effort for more than a half of century based on an inadequate level of development. In addition, the important role of the militaryindustrial complex in the economic decisions of states is often emphasized, even though the rules of the World Trade Organization exclude all matters relating to national security.

Challenges to dominant economic theory (from Marxism but also from Keynesian thinking) will contribute to deepening the analysis of war and the role of the military sector in modern capitalist societies. More interestingly, the late 20th century has seen a resurgence of mercantilist ideas about the concept of 'economic warfare'. The long-term horizons, which prevailed before the 20th century, have given way to short-term analyses, with sometimes contradictory results.

Although never proved, the 'invisible hand' is supposed to lead to peace, not today, but tomorrow, in the promised 'bright future'. When Marx denies the coherence of capitalism and its ability to be peaceful, he is nonetheless convinced that communism will inaugurate 
an era of eternal peace. In other words, economists have generally always been in search of peace, which can only be ensured by adequate economic organization. They are adherents of peace. The analysis of war, peace and defence is, sometimes unwittingly, at the heart of essential reflections on the foundations of the economy, its objectives, its organization, and its expected results. Today, however, economics lacks a soul. It is no longer able to replenish its resources by drawing on the rich veins of philosophical reflection concerning the real foundations of the economy and, in sum, concerning its own role.

References

Coulomb, F. (1997) La révolution keynésienne: une conséquence inattendue de l'analyse de la sécurité internationale de l'entre-deux guerres. Cahiers de l'Espace Europe, Contribution en l'honneur du Pfr Robert Eisner, Grenoble.

Coulomb, F. (1998a) Adam Smith, economist of defence. Defence and Peace Economics 9(1) 299-316.

Coulomb, F. (1998b) Economic theories of war, peace and defence. From the origins to the present day. $\mathrm{PhD}$ thesis,

Coulomb, F. and Fontanel, J. (2000) Disarmament in the next millennium. Defence and Peace EConomics 11(1) 105-125.

Coulomb, F. and Fontanel J. (2003) Disarmament, a century of economic thought. Defence and Peace Economics, Special issue edited by J. Brauer, 14(3) 193-208.

Davenant, C. (1697) Discourse on the public revenues and on trade. In Mercantilism, the Shaping of an Economic Language, Volume III, edited by Lars Magnusson. London, New York: Routledge.

Engels, F. (1878) Antidühring. Paris: Editions sociales. Fontanel, J. (2005) La globalisation en analyse. Collection Côté Cours, Paris: L’Harmattan. Hobbes, T. (1998 [1651]) Leviathan. Oxford: World's Classics.

Lapidus, A. (1996) Introduction à une Histoire de la pensée économique qui ne verra jamais le jour. Revue Economique 4(July) 867-892.

List, F. (1857 [1841]) Système national d'économie politique. Paris: Capelle Éditeur. Locke ([1960] 1690) The Second Treatise of Government, subtitled An Essay Concerning the True Original Extent and End of Civil Government, edited by P. Laslett. Cambridge: Cambridge University Press.

Machiavelli, N. (1961 [1513]) The Prince. London: Penguin Books. Magnusson, L. (ed.) (1994) Mercantilism, the Shaping of an Economic Language. London, New York: Routledge.

Malthus, T.R. (1798) An Essay on the Principle of Oopulation, London, printed for J. Johnson, in St. Paul's

Church-Yard. Marx, K. (1867) Le capital. Paris: La Pléiade, 1968. Montchrestien de, A. (1615) Traicté de I'économie politique, Edition Plon. Paris: Nourrit et Cie, 1889.

Mun, T. (1664) English treasure by forraign trade. In Mercantilism, the Shaping of an Economic Language, Volume I, edited by Lars Magnusson. London, New York: Routledge.

Smith, A. (2000 [1776]) An Inquiry into the Nature and Causes of the Wealth of Nations. Edwin Cannan, Modern Library Paperback Classics.

Wrigley, E.A. and Souden, D. (1986) The Works of Thomas Robert Malthus. London: William Pickering. 